\title{
Industrial Wastes as Alternative Mineral Addition in Portland Cement and as Aggregate in Coating Mortars
}

\author{
Kamilla Almeida Oliveira ${ }^{a}$, Bruna Inácio Nazário ${ }^{b}$, Antonio Pedro Novaes de Oliveira ${ }^{a}$,
}

\author{
Dachamir Hotza ${ }^{a}$, Fabiano Raupp-Pereira ${ }^{a}$
}

\author{
${ }^{a}$ Graduate Program in Materials Science and Engineering (PGMAT), Laboratory of Glass-Ceramic \\ Materials (VITROCER), Universidade Federal de Santa Catarina (UFSC), PO Box 476, 80040-900, \\ Florianópolis, SC, Brazil. \\ ${ }^{b}$ Graduate Course in Environmental Engineering, Laboratory of Technical Ceramics (CERTEC), \\ Universidade do Extremo Sul Catarinense (UNESC), 88806-000, Criciúma, SC, Brazil.
}

Received: December 31, 2016; Revised: July 22, 2017; Accepted: August 01, 2017

\begin{abstract}
This paper presents an evaluation study of wastes from pulp and paper as well as construction and demolition industries for application in cement-based materials. The alternative raw materials were used as a source of calcium carbonate $\left(\mathrm{CaCO}_{3}\right)$ and as pozzolanic material (water-reactive $\mathrm{SiO}_{2}$ ) in partial replacement of Portland cement. In addition to the hydraulic binder, coating mortars were composed by combining the pulp and paper fluidized bed sand residue with construction and demolition wastes, both added as small aggregates. Rheological and mechanical characterization showed that the waste additions changed the behavior of the cement materials, increasing both the viscosity of the pastes (at constant shear stress or rate). The formation of agglomerates in the cement hydration process made the mortars with additions of residues (lime and ash sludge) have an increase in the mechanical strength of the hardened bodies when compared to the mortar (M0W) prepared only with the residues (fluidized bed sand and C \& D) as aggregates.
\end{abstract}

Keywords: Industrial wastes, pulp and paper, construction and demolition industry, coating mortars.

\section{Introduction}

Brazil is the fourth highest cellulose producer, and the ninth paper producer in the world. In 2014, 16.5 million tons of cellulose were produced worldwide, which is an increase of $8.8 \%$ when compared to 2013 . The paper industry grew $1.8 \%$ in this same period, totalizing 10.6 million tons ${ }^{1}$.

The residues from these industries like: lime mud, fly ash and fluidized beds sand are often employed as soil acidity corrective material ${ }^{2,3}$, fertilizer ${ }^{4}$ and additive for road paving 5 . Moreover, wastes from the pulp and paper industry are excellent examples of materials with potential value as alternative raw material to the cement industry. If we consider the geographical proximity of the pulp and paper industries with those of cement in Brazil, as shown in Figure 1, it is possible to identify the possibility of interaction between these activities, the cement industry as a possible consumer of the by-products generated by the paper and cellulose.

The lime sludge consists predominantly of $\mathrm{CaCO}_{3}{ }^{8}$ calcium carbonate. The biomass ash is rich in quartz silica with constant and homogeneous particle size, according to the literature, which would be suitable for use as small aggregates in building concrete, unidentified fact in the study $\operatorname{ash}^{9}$
These industrials wastes can be a real alternative source for sustainable development in the civil construction industry. According to Brazilian Association of Public Cleaning and Special Waste Companies (ABRELPE) (2014), Brazil collected in 2014, 45 million tons of construction and demolition (C\&D) wastes $^{10}$. However, the wastes valorization should present a holistic and systemic perspective in order to correlates fundamental factors to enhance applicability and to ensure sustainability. Other important aspect is waste management ${ }^{11}$, becauseit's estimated that $50 \%$ of solid wastes generated by all human activities comes from industry of the construction ${ }^{12}$.

Considered a composite material, mortar can be defined by its main components: cement, small aggregate and water. The use of residues as additions, in substitution of cement, or as aggregates incorporated in traditional mixtures, bring about several changes in the properties and performances of this material.

On a rheological viewpoint, the concrete can be understood as a concentration of solid suspended particles (small aggregates, which in the case of mortars) in a liquid (cement paste) $)^{13}$. Therefore, to study the effect of the use of residues on this rheological system, favors the knowledge of the alteration resulting from the use of alternative raw materials. 


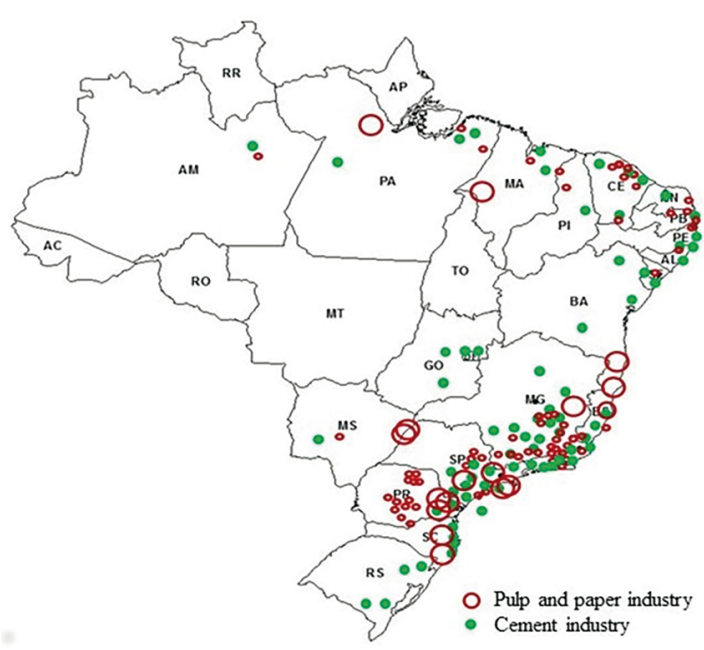

Figure 1. Geographical distribution of paper/pulp and cement industries in Brazil. (Adaptation BRACELPA, 2014 e SNIC, 2013) (6, $^{6}$

This study aims to evaluate the influence of pulp and paper industry residues (ash and lime mud) as mineral additions to Portland cement through on rheological behavior of cement pastes. Aggregates of sand from fluidized beds, also from the paper and cellulose industry and C\&D waste, were added to coating mortars to assess the mechanical properties.

\section{Materials and Methods}

The experimental mixtures were comprised of a type- $\mathrm{V}$ Portland cement (CPV-ARI), a workability additive (TPF-Na, $\mathrm{Na}_{5} \mathrm{P}_{3} \mathrm{O}_{10}$ ), normalized sand according to NBR 7214:1982 14 and the residual additives biomass ash, lime mud, sand from fluidized beds from a Brazilian pulp and paper industry, and C\&D waste from local origin.

The Portland cement was characterized in terms of chemical composition by X-ray fluorescence (XRF, WDXRF Axios Max Panalytical), particle size distribution by dynamic laser scattering (DLS, Mastersizer 3000, Malvern), surface area (BET, Quantachrome Instruments - Autosorb-1). The wastes from the pulp and paper industry are classified as hazardous according to ABNT NBR 10.004:2004'15. The mineralogical composition was determined by X-ray diffraction (XRD, XRD-6000, Shimadzu), the patterns were scanned in the $2 \theta$ range of $10-80^{\circ}, 0.02^{\circ} / \mathrm{s}$ step and the thermal behavior was evaluated by thermogravimetric and differential thermal analysis, DTA/TG (TA Instruments, SDT Q600 - Simultaneous TGA - DSC/DTA, USA) at a heating rate of $10{ }^{\circ} \mathrm{C} / \mathrm{min}$ with a flow of synthetic air $\left(20 \% \mathrm{O}_{2}\right.$ and $80 \% \mathrm{~N}_{2}$ ). The specific mass was determined by pycnometry (Ultrapyc 1200e). The waste moisture was measured by mass loss after a treatment in $110^{\circ} \mathrm{C}$ for $24 \mathrm{~h}$. The morphology was observed by scanning electronic microscopy (SEM, - JSM$6390 \mathrm{LV}, \mathrm{Jeol})$. The anhydrous sulfur content $\left(\mathrm{SO}_{3}\right)$ was also determined for ash and lime mud according to NM 50:1996 and NM 16:2004. The methodology proposed by Luxán $(1989)^{16-18}$ was applied to identify the pozzolanic activity of the fly ash. According to this method, the pozzolanic activity is classified as low $(\Delta<0.4 \mathrm{mS} / \mathrm{cm})$, (ii) moderate $(0.4<\Delta<1.2)$ or (iii) high $(\Delta>\mathrm{mS} / \mathrm{cm}>1.2)^{18}$. The C\&D residues used in this study come from a building materials processing unit. The selection of the material was based on the classification criteria of NBR $15116^{19}$, where a class A material was obtained, according to Annex A of that standard. The C\&D wastes were prepared in order to replace normalized sand (NBR 7214/1982) as aggregate, in compliance with the requirements of CONAMA 307:2002 ${ }^{20}$. Subsequently this waste was ground in a hammer mill (Servitech) to achieve the size specified in NBR 7215:1996 ${ }^{21}$. Afterwards, cement pastes were prepared using the waste materials and evaluated by rheological flow tests.

Cement pastes were prepared in a mechanical mixer (QS20-5) at $300 \mathrm{rpm}$ for $3 \mathrm{~min}$. The rheological characterization was performed in a rotational viscometer with concentric cylinders geometry (VT 500, Thermo Haake), at $25.0 \pm$ $0.5^{\circ} \mathrm{C}$, in 5 and $30 \mathrm{~min}$ after contact of the cement with water. The flow behavior was assessed with variation of shear rate from 0 to $600 \mathrm{~s}^{-1}$ (upward curve) and 600 to $0 \mathrm{~s}^{-1}$ (downward curve), in $180 \mathrm{~s}$.

Cement pastes were formulated and produced according to the proportions in percentage mass shown in Table 1. The mortars were prepared according to NBR 7215:1996, cement: aggregate ratio (1:3) and water/cement ratio of 0.48 . The aggregate (standard sand) was replaced by wastes (sand from the fluidized bed of pulp and paper industry corresponding to the fraction of $0.6 \mathrm{~mm}$, and C\&D wastes in the other standard particle size ranges).

Table 1. Formulations of cement pastes (mass percent).

\begin{tabular}{cccc}
\hline Formulation & Portland CPV & Biomass Ash & Lime mud \\
\hline P0 & 100 & - & - \\
P15 & 85 & 10 & 5 \\
P20 & 80 & 10 & 10 \\
P25 & 75 & 20 & 5 \\
\hline
\end{tabular}

For compare the effect of the mineral additions (ash and lime mud) on the mortar performance, two reference formulations were prepared with cement paste without mineral addition: M0S and M0W. The first containing cement, water and standard sand; the second, cement, water and waste (fluid bed sand and C\&D waste), as presented in Table 2.

For each mortar formulation four samples were molded with nominal dimensions of $30 \times 30 \times 30 \mathrm{~mm}$. After molding, the samples remained 7 days curing immersed in water saturated with lime. Subsequently, a uniaxial compression test was performed (DL 2000, EMIC) using a load cell of $20 \mathrm{kN}$, with loading speed of $1 \mathrm{~mm} / \mathrm{min}$. 
Table 2. Formulations of mortars (mass percent).

\begin{tabular}{ccccc}
\hline $\begin{array}{c}\text { Formulation } \\
\text { Mortars }\end{array}$ & $\begin{array}{c}\text { Cement } \\
\text { Pastes }\end{array}$ & $\begin{array}{c}\text { Standard } \\
\text { Sand }\end{array}$ & $\begin{array}{c}\text { Sand of } \\
\text { Fluidized } \\
\text { Bed }\end{array}$ & $\begin{array}{c}\text { C\&D } \\
\text { Waste }\end{array}$ \\
\hline M0S & P0 & $\mathrm{X}$ & & \\
M0W & P0 & & $\mathrm{X}$ & $\mathrm{X}$ \\
M15\% & P15 & $\mathrm{X}$ & $\mathrm{X}$ \\
M20\% & P20 & $\mathrm{X}$ & $\mathrm{X}$ \\
M25\% & P25 & & $\mathrm{X}$ & $\mathrm{X}$ \\
\hline
\end{tabular}

\section{Results and Discussion}

The residues of biomass ash, lime mud and fluidized bed sand did not present any leached compound according to the parameters of NBR 10005:2004, in accordance with NBR 10004:2004. However, the different compounds (aluminum, cadmium, lead, copper, chromium and iron) were solubilized in values above the maximum limit allowed by NBR 10006:2004 22,23 . For this reason, all residues were classified as Class II A (non-inert) residue due to the solubilization of the compounds mentioned above ${ }^{24}$. The incidence of these contaminants is derived from the use of water-soluble fertilizers in industrial pine and eucalyptus forests ${ }^{25}$.

The chemical composition of Portland CP V cement and the wastes of cellulose and paper industry are shown in Table 3. It is possible to notice a high concentration of $\mathrm{SiO}_{2}$ for biomass ash and fluidized beads sand, 49.65\% and $93.65 \%$, respectively. Lime mud presented a high $\mathrm{CaO}$ concentration of $53.55 \%$. The chloride content was lower than $0.1 \%$ for lime mud and biomass ash.

Table 3. Chemical composition (mass percent) by XRF of the Portland cement and industrial wastes.

\begin{tabular}{|c|c|c|c|c|}
\hline Oxides & $\begin{array}{c}\text { Cement } \\
\text { Portland } \\
\text { (CP V) }\end{array}$ & $\begin{array}{c}\text { Biomass } \\
\text { Ash }\end{array}$ & $\begin{array}{l}\text { Lime } \\
\text { mud }\end{array}$ & $\begin{array}{c}\text { Sand } \\
\text { fluidized } \\
\text { beds }\end{array}$ \\
\hline $\mathrm{Al}_{2} \mathbf{O}_{3}$ & 3.30 & 9.94 & 0.22 & 0.73 \\
\hline $\mathrm{SiO}_{2}$ & 15.00 & 49.65 & 1.06 & 98.29 \\
\hline $\mathrm{Fe}_{2} \mathrm{O}_{3}$ & 3.40 & 4.07 & 0.16 & 0.56 \\
\hline $\mathrm{CaO}$ & 65.60 & 2.10 & 53.55 & $<0.05$ \\
\hline MgO & 4.60 & 1.25 & 0.91 & $<0.05$ \\
\hline $\mathrm{Na}_{2} \mathrm{O}$ & 0.20 & 0.33 & 1.06 & $<0.05$ \\
\hline $\mathbf{K}_{2} \mathbf{O}$ & 0.90 & 3.14 & $<0.05$ & $<0.05$ \\
\hline $\mathrm{TiO}_{2}$ & 0.40 & 0.95 & $<0.05$ & $<0.05$ \\
\hline MnO & - & 0.24 & 0.10 & $<0.05$ \\
\hline $\mathbf{P}_{2} \mathbf{O}_{5}$ & 0.10 & 0.65 & 0.65 & $<0.05$ \\
\hline $\mathrm{Cr}_{2} \mathrm{O}_{3}$ & - & 0.08 & - & 0.11 \\
\hline $\begin{array}{c}\text { Loss on } \\
\text { Ignition (LOI) }\end{array}$ & 3.70 & 26.97 & 42.25 & $<0.39$ \\
\hline $\mathrm{SO}_{3}$ & 2.70 & - & - & - \\
\hline
\end{tabular}

Figure 2 shows the diffractogram of biomass ash and lime mud. The ash presents, with approximately $28 \%$ crystalline phase, quartz $\left(\mathrm{SiO}_{2}, \mathrm{ICSD}\right.$ - 46-1045), as determined by Rietveld refinement. According to Buruberri et al. (2014) this is characteristic from the contamination with sand of the fluidized bed. In this case, $72 \%$ of silica is in the reactive form (deviation in the baseline between the angles of 15 to $\left.40^{\circ}\right)^{26}$. The reactivity characterized by the structural amorphism of the ashes is confirmed by the moderate pozzolanic activity ( $\Delta=1.1 \mathrm{mS} / \mathrm{cm}$ ) determined by the Luxán method (Luxán, $1989)^{18}$. XRD analysis of lime mud identified only a single phase- calcite $\left(\mathrm{CaCO}_{3}\right.$, ICSD - 5-5086). The $\mathrm{CaO}$ content may also be associated with $39.48 \%$ of mass loss and thermal reactions detected by TG and DTA (see Figure 3).

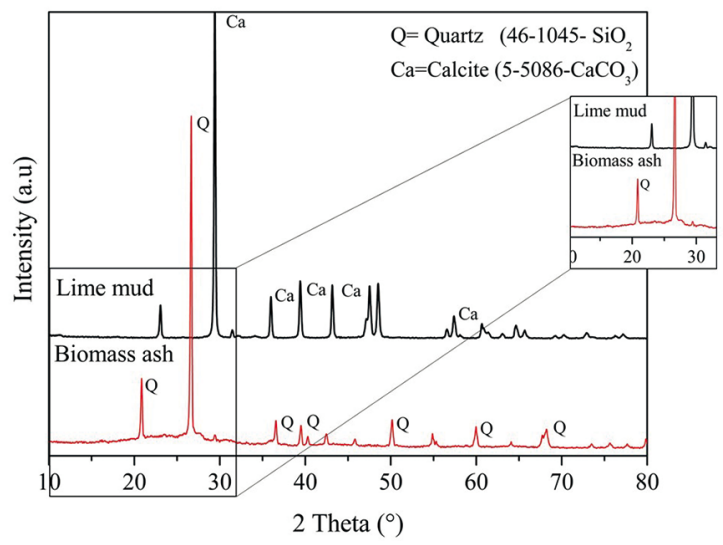

Figure 2. XRD of biomass ash and lime mud. The detail shows the deviation in the baseline between the angles of 15 to $40^{\circ}$.

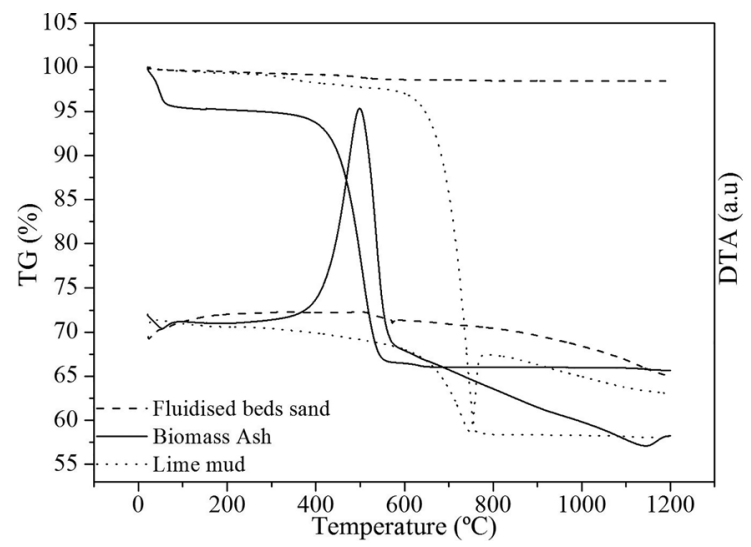

Figure 3. DTA/TG of the sand fluidized bed sand, biomass ash and lime mud.

The decarbonation of lime mud (Figure 3 ) corresponds to the endothermic peak at $745^{\circ} \mathrm{C}\left(\right.$ decomposition of $\left.\mathrm{CaCO}_{3}\right)$. The fly ash shows an exothermic peak at $500^{\circ} \mathrm{C}$, associated to a mass loss of $34 \%$ due to the incomplete combustion of organic matter, due to the low efficiency of the boiler. 
The sand presented a characteristic thermal behavior with very low mass loss $(1.4 \%)$. This result confirms the loss on ignition obtained by the chemical analysis, indicating a low amount of contaminants.

The particle size distribution of the powdered wastes is shown in Table 4. Among the waste materials, the biomass ash presents the highest mean particle size $\left(\mathrm{D}_{50}\right), 75 \mu \mathrm{m}$, which can be attributed to the irregularly shaped and porous particles after rupture of wood fibers during the Kraft process. Figure 4 shows the irregular morphological aspect of fly ash (fibers) (Figure 4a) and the regular and spheroidal shape of lime mud (Figure 4b). Moreover, Portland cement CP V presented the highest surface area when compared to the waste materials.

Table 4. Characterization of the powders: Portland cement CP V, biomass ash and lime mud.

\begin{tabular}{cccc}
\hline Property & $\begin{array}{c}\text { Portland } \\
\text { CP V }\end{array}$ & $\begin{array}{c}\text { Biomass } \\
\text { ash }\end{array}$ & $\begin{array}{c}\text { Lime } \\
\text { mud }\end{array}$ \\
\hline BET Surface area $\left(\mathrm{m}^{2} / \mathrm{g}\right)$ & 75.00 & 33.44 & 14.77 \\
Density $\left(\mathrm{g} / \mathrm{cm}^{3}\right)$ & 3.10 & 2.49 & 2.91 \\
Mean particle size, $\mathrm{D}_{50}(\mu \mathrm{m})$ & 12.5 & 75.0 & 22.0 \\
\hline
\end{tabular}

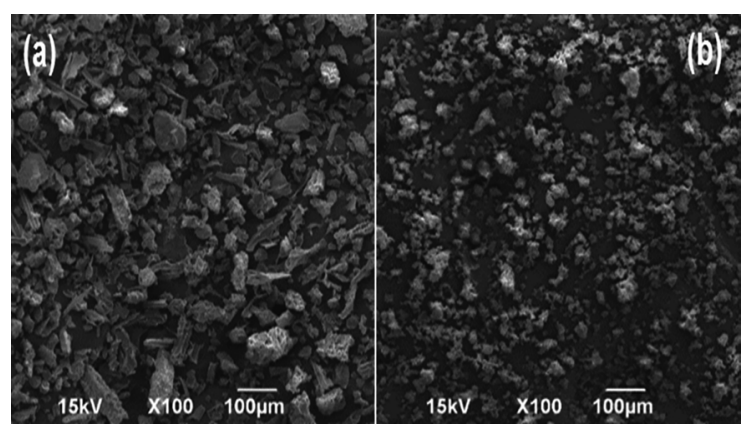

Figure 4. Micrographs (SEM) of the wastes: (a) biomass ash; and (b) lime mud.

Based on previous analyses, the potentiality of using those wastes as partial replacement of Portland cement was identified for fly ash and lime mud. Biomass ash presents a chemically reactive binder component, as revealed by XRF, structural amorphism according to XRD, and moderate pozzolanic activity. Lime mud is a carbonate source, a chemically inert binder, as determined by XRF, XRD and DTA/TG.

In terms of rheological behavior, as seen in Figure 5, cementitious pastes require an shear stress (or yield stress) to initiate the flow. For pastes P15, P20 and P25 (see Table 1), the shear stress presented intense increments between 5 and $30 \mathrm{~min}$. On the other hand, the sample P0 remained practically constant, with no formation of agglomerates, only loss of water, due to the onset of hydration of the cement ${ }^{27}$.

The increase of yield stress reflects the interaction of cement additions along the analyzed hydration time ${ }^{27}$. Cement dissolution/precipitation, and physical phenomena such as agglomeration of the particles in aqueous media, influence directly the rheological properties of the cementitious paste ${ }^{28}$.

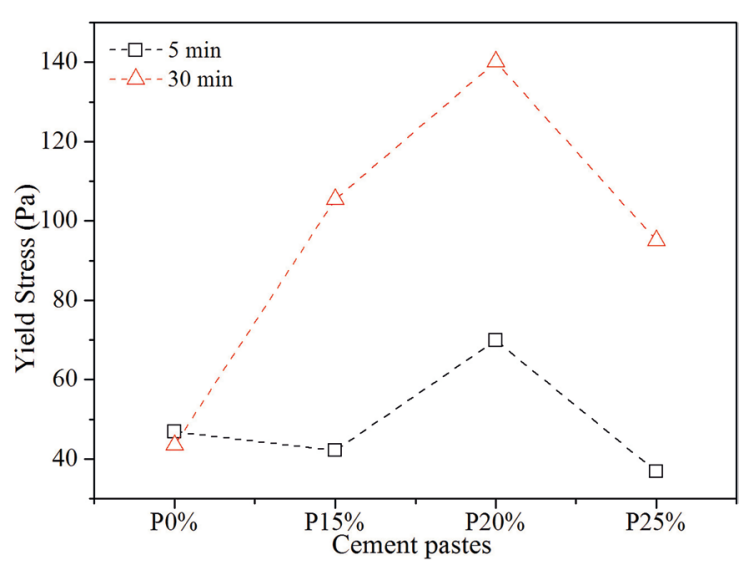

Figure 5. Yield stress at 5 and 30 min for cement pastes P0, P15, $\mathrm{P} 20$ and $\mathrm{P} 25$.

Particularly, agglomeration is related to electrostatic or van der Waals forces, ionic strength of the aqueous medium and formation of hydrated products ${ }^{29}$. As Betioli (2009) observed in measurements carried out in the induction period, similar to this study, show an increase in the yield stress associated to the physical phenomenon of agglomeration. Although, the ash presents moderate pozzolanic activity, as identified by the method proposed by Luxán ${ }^{18}$, the phenomena observed are not caused by hydration reactions. In the early ages the mineral additions act as inert, fine materials, Physical action of forming agglomerates, since the chemical reactions do not occur in the same proportion as the cement hydration reactions, having its rheological behavior controlled by the molecular physical interaction characteristics of the additions to the cement ${ }^{29-31}$.

The pastes present a pseudoplastic behavior, as depicted in Figure 6, with a decrease of viscosity for increasing shear rates. However due to the presence of flow stress the rheological behavior of the cement pastes is characterized as Bingham fluid ${ }^{32}$. The decrease in the viscosity of the cementitious pastes is associated with the increase in shear rate which may lead to the breaking of the agglomerated particles, thus reducing the turbulence of the flow lines due to reduction the diameter of the agglomerate ${ }^{28}$.

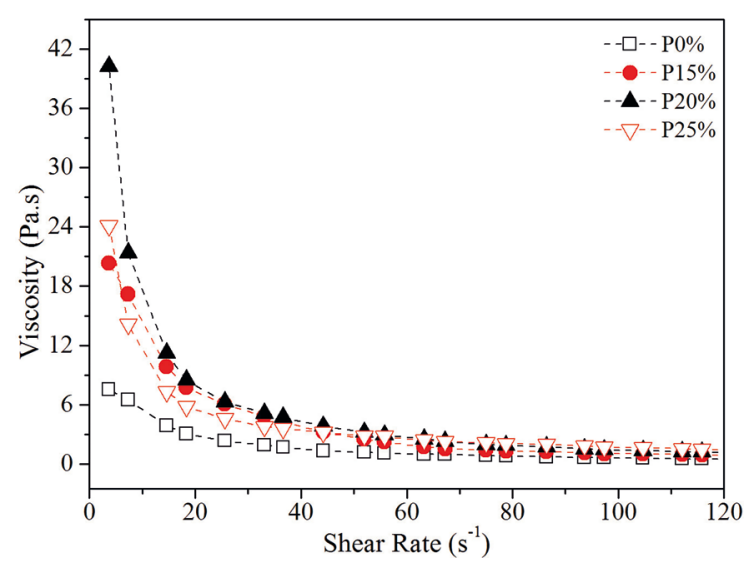

Figure 6. Apparent viscosity of cement pastes with P0, P15, P20 and $\mathrm{P} 25$ after $30 \mathrm{~min}$. 
It's observed that the formulation with high concentration of lime sludge presented higher flow stress (Figure 5 - P20) and higher viscosity in the shear rate range of 0 to $20 \mathrm{~s}^{-1}$ (Figure 6 - P20). This phenomenon may be associated with a greater tendency of agglomeration of the finer particles and with a decreasing of mean free path, since the mud presents $1 / 3$ of the average diameter of the ashes, as show in Figure $5^{33}$.

It's notable for the cement paste P15 and P25 samples lower viscosity when compared to the P20 sample. Such behavior is justified by the ashes morphology. The fiber format provides a sharp drop in viscosity after the application of shear rate due to aligning of particles in the flow direction imposed during the test. This behavior is evidenced by the lower yield stress presented for the sample of $25 \%$ of addition (P25), sample with higher ash content (Figure 5) ${ }^{33}$.

Analyzing the flow curves, Figure 7, it's possible to notice that the sample without addition, $\mathrm{P} 0$, showed a typical rheological behavior of cement paste ${ }^{27-32}$. The hysteresis loop, corresponding to the area between the upward and downward curve, represents the energy required for breaking the structures formed by the hydration of the cement. The rheological behavior of Bingham was the one that best suited the results of cement pastes. Thus, the characterization is

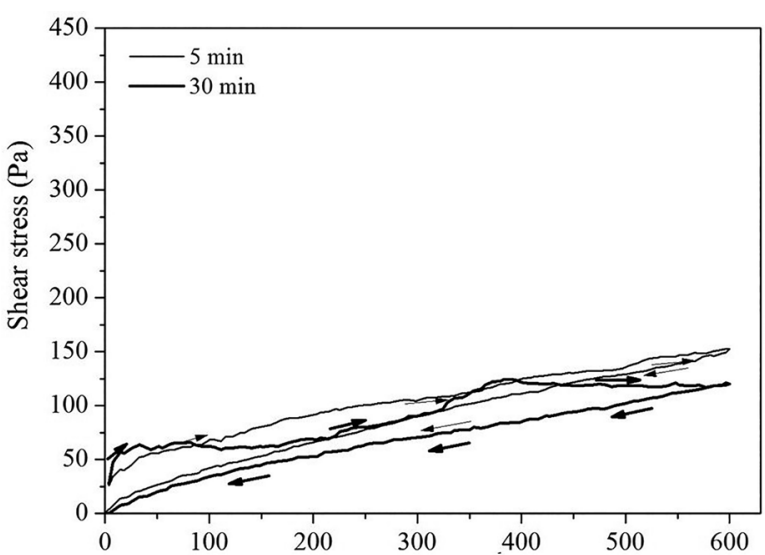

(a)

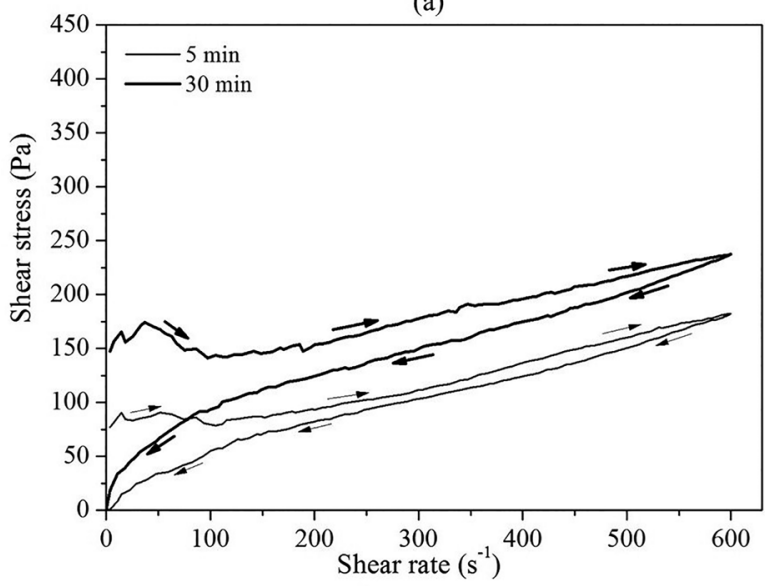

(c) restricted to the range $\left(0 \mathrm{~s}^{-1}\right.$ to $\left.600 \mathrm{~s}^{-1}\right)$ of the shear rate, and may vary according to the type of material application ${ }^{31}$.

The additions (ash and lime mud) increased the viscosity of the cement pastes; consequently, a higher energy is required to break the formed structures ${ }^{34}$. All formulations (Figure 6) when subjected to increasing shear rates up to $600 \mathrm{~s}^{-1}$, showed an increase in shear stress, associated to the decrease of viscosity, as shown in the upward curves. The downward curves present systematically lower levels of shear stress for a given shear rate. This behavior results from the breakage of the agglomerates formed by the hydration of cement, which can be associated to pseudoplasticity and thixotropy ${ }^{32}$. The curves after $30 \mathrm{~min}$, when compared to the 5-min curves, present the same trend of higher viscosities at constant shear rate or stress, due to the hydration of the cement ${ }^{32}$.

The cement pastes were mixed with fine aggregates (sand from fluidized bed and construction and demolition waste) in order to prepare mortars (Table 2). The M0S mortar was prepared for compare to the mortars without the incorporation of waste. Thus the amount of water used in the mortar was increased to a water/cement ratio of 0.63 . This was necessary because the fine particles of C\&D wastes demand a greater amount of water, due to the high absorption capacity and the angular shape of those aggregates ${ }^{12}$.

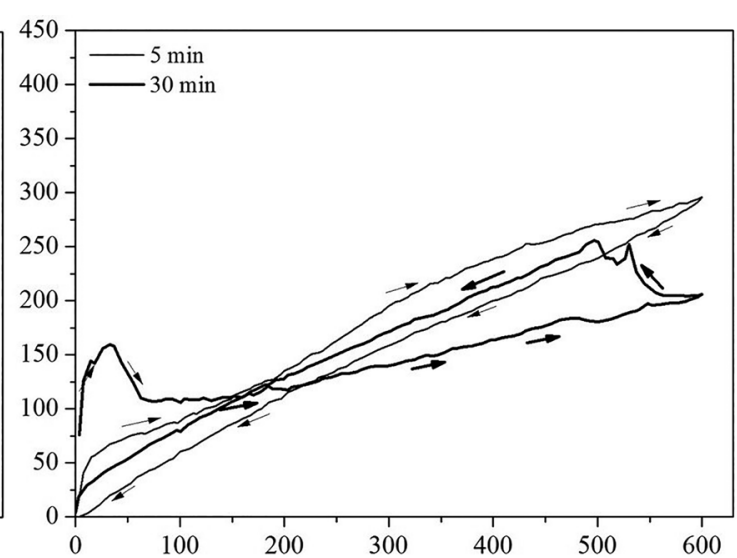

(b)

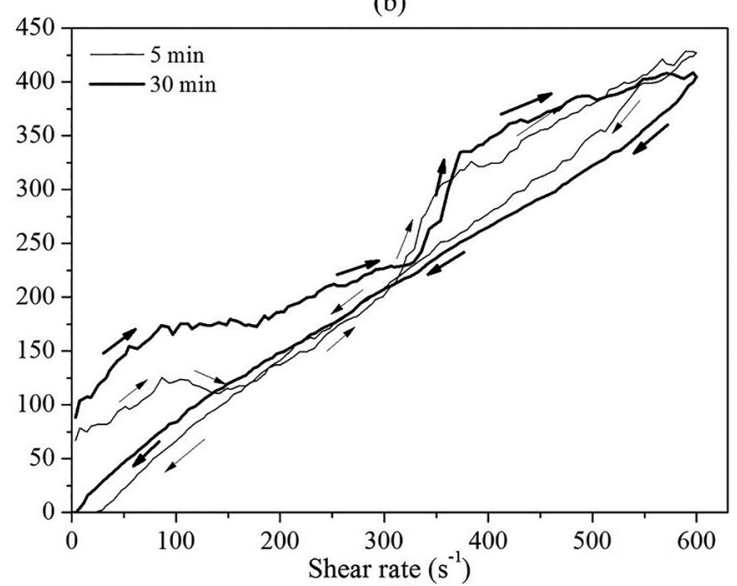

(d),

Figure 7. Flow curves for 5 and 30 min (bold line) of the formulated pastes of cements: (a) P0; (b) P15; (c) P20; and (d) P25. 
As expected, samples containing C\&D wastes presented lower mechanical strength (Figure 8), when compared to the samples with normalized aggregates $(\mathrm{M})$, mainly due to the intrinsic physical characteristics, such as high porosity and high water absorption ${ }^{12}$. However, it is possible to notice the increase in resistance when the mortar has been prepared with pastes-mineral additions ( $\mathrm{CPV}+$ wastes). This gain of resistance can be attributed to the physical effect, the fineness of the additions that promoted a greater densification of the matrix/aggregate, causing a filling of the existing pores and a reduction of the spaces available for water. In this way, the contact between the hydrated and non-hydrated products of the matrix increased, which is a greater packaging of the matrix. This higher contact, consequently represented a greater increase of the resistance to compression ${ }^{35}$.

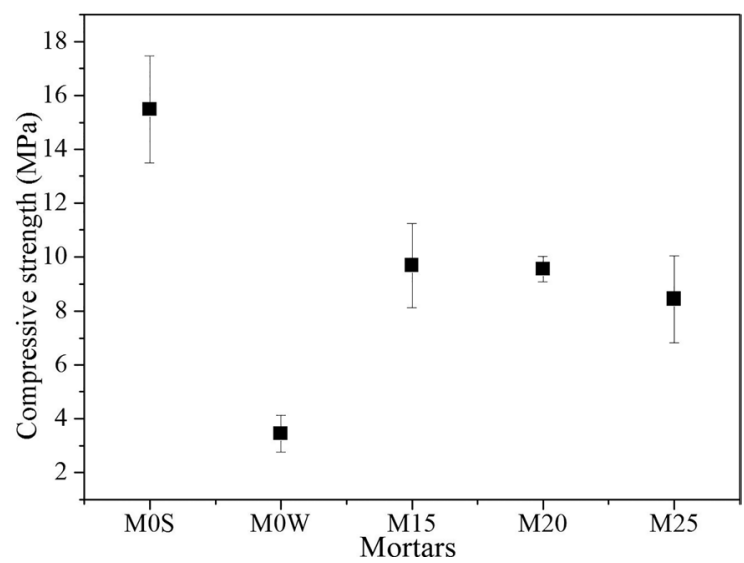

Figure 8. Compressive strength for mortars M0S, M0W, M15, M20, and M25 at 7 days old.

The agglomerates formed, permanent or not, in the cement paste besides altering the rheological response, interfered in the packing of the particles and consequently in the mechanical resistance of the mortars, as showed in the work of Castro and Pandolfelli ${ }^{28}$. Resulting in resistances, with maximum intermediate strains reference samples, as observed by results of mechanical resistance (Figure 8).

The sample (M20) had the lowest standard deviation among samples containing additions. A possibility for the regularity between the resistances can be attributed to lime mud, a filler, of regular morphology and of low granulometry. It assumes that the lime sludge has acted as a lubricant for the aggregates (fluid bed sand and C\&D waste) of the mortar. Favoring the best packaging of the particles, and increasing of mechanical resistance.

\section{Conclusions}

The residues studied have the potential to be used in the development of alternative cement mortars as partial replacement of Portland cement, as incorporated mineral additions (ash and lime sludge), or as small aggregates (fluidized bed sand and waste of C\&D). However, the results it's suggested a better evaluation of the compressive strength after 14, 21 and 28 days of hydration. This assessment should be associated with mineralogical and thermal analyses. In this way, it will be possible to evaluate the action of the mineral additions after the induction period, according to chemical reactions of the cement pastes, and their effect on mortar performance. The use of new materials in the construction industry is a great opportunity for valorization of solid industrial waste in the paper and pulp sector, given the great demand of the sector and the geographical proximity between these two industries. In addition, it become important to highlight the sustainability attributed to waste valorization through lower $\mathrm{CO}_{2}$ emissions and lower consumption of cement by substitution for mineral additions.

\section{Acknowledgments}

The authors would like to thank FAPESC/CNPq (Project Pronex, T.O. No. 17431/2011-9) for financial support, as well as to $\mathrm{CNPq}$ for the granting of scholarships.

\section{References}

1. Indústria Brasileira de Árvores (IBA). Relatório IBA 2015. Brasília: IBA; 2015. p. 34. Available from: $<$ http://iba.org/ images/shared/iba_2015.pdf $>$. Access in: 7/8/2017.

2. Almeida HC, Silveira CB, Ernani PR, Campos ML, Almeida D. Composição química de um resíduo alcalino da indústria de papel e celulose: Dregs. Química Nova. 2007;30(7):1669-1672.

3. Medeiros JC, Albuquerque JA, Mafra AL, Batistella F, Grah J. Calagem superficial com resíduo alcalino da indústria de papel e celulose em um solo altamente tamponado. Revista Brasileira de Ciência do Solo. 2009;33(6):1657-1665.

4. Ingerslev M, Hansen M, Pedersen LB, Skov S. Effects of wood chip ash fertilization on soil chemistry in a Norway spruce plantation on a nutrient-poor soil. Forest Ecology and Management. 2014;334:10-17.

5. Silva FC. Reaproveitamento de areia de caldeiras de leito fluidizado. Eucalyptus Online Book \& Newsletter; 2012. Available from: $<$ http://www.eucalyptus.com.br/eucaexpert/1199 Reaproveitamento\%20areia\%20caldeiras $\% 20 \mathrm{de} \% 201$ eito $\% 20$ fluidizado.pdf $>$. Access in: 7/8/2017.

6. Indústria Brasileira de Árvores (IBA). Relatório IBA 2014. Brasília: IBA; 2014. Available from: <http://iba.org/images/ shared/iba_2014_pt.pdf>.Access in: 7/8/2017.

7. Sindicato Nacional da Indústria de Cimento (SNIC). Relatório Anual. 2013. Rio de Janeiro: SNIC; 2013. Available from: http:/ www.snic.org.br/pdf/RelatorioAnual2013final.pdf. Access in: 7/8/2017.

8. Pérez-López R, Castillo J, Quispe D, Nieto JM. Neutralization of acid mine drainage using the final product from $\mathrm{CO}_{2}$ emissions capture with alkaline paper mill waste. Journal of Hazardous Materials. 2010;177(1-3):762-772. 
9. Modolo RCE, Ferreira VM, Tarelho LA, Labrincha JA, Senff L, Silva L. Mortar formulations with bottom ash from biomass combustion. Construction and Building Materials. 2013;45:275281.

10. Associação Brasileira de Empresas de Limpeza Pública e Resíduos Especiais (ABRELPE). Panorama dos Resíduos Sólidos no Brasil. 2014. São Paulo: ABRELPE; 2014. Available from: <http://www.abrelpe.org.br/Panorama/panorama2014. pdf $>$. Access in: 7/8/2017.

11. Raupp-Pereira F, Hotza D, Segadães AM, Labrincha JA. Ceramic formulations prepared with industrial wastes and natural subproducts. Ceramics International. 2006;32(2):173-179.

12. Cabral AEB. Concrete with construction and demolition wastes (CDW). In: Pacheco-Torgal F, Jalali S, Labrincha J, John VM, eds. Eco-Efficient Concrete. Cambridge: Woodhead Publishing; 2013. p. 340-367.

13. Ferraris CF. Measurement of Rheological Properties of High Performance Concrete: State of the Art Report. Journal of Research of the National Institute of Standards and Technology. 1999;104(5):461-478.

14. Associação Brasileira de Normas Técnicas (ABNT). NBR 7214/1982 - Areia normal para ensaio de cimento. Rio de Janeiro: ABNT; 1982.

15. Associação Brasileira de Normas Técnicas (ABNT). NBR 10.004/2004 - Resíduos sólidos - Classificação. Rio de Janeiro: ABNT; 2004.

16. Associação Brasileira de Normas Técnicas (ABNT). NBR NM 50 - Agregados para concreto - Determinação de sais, cloretos e sulfatos solúveis. Rio de Janeiro: ABNT; 1996.

17. Associação Brasileira de Normas Técnicas (ABNT). NBR NM 16/2004 - Cimento Portland - Análise Química - Determinação de anidro sulfúrico. Rio de Janeiro: ABNT; 2004.

18. Luxán MP, Madruga F, Saavedra J. Rapid evaluation of pozzolanic activity of natural products by conductivity measurement. Cement and Concrete Research. 1989;19(1):63-68.

19. Associação Brasileira de Normas Técnicas (ABNT). NBR 15116/2004 - Agregado reciclados de resíduos sólidos da construção civil - Utilização em pavimentação e preparo de concreto sem função estrutural: Requisitos. Rio de Janeiro: ABNT; 2004.

20. Brazil. Ministério do Meio Ambiente. Conselho Nacional do Meio Ambiente (CONAMA). Resolução CONAMA $n^{\circ} 307$. Estabelece diretrizes, critérios e procedimentos para a gestão dos resíduos da construção civil. Brasília: CONAMA; 2002.

21. Associação Brasileira de Normas Técnicas (ABNT). NBR 7215/1996 - Cimento Portland - Determinação da resistência à compressão. Rio de Janeiro: ABNT; 1996.
22. Associação Brasileira de Normas Técnicas (ABNT). NBR 10005/2004 - Procedimento para obtenção de extrato lixiviado de resíduos sólidos. Rio de Janeiro: ABNT; 2004.

23. Associação Brasileira de Normas Técnicas (ABNT). NBR 10006/2004 - Procedimento para obtenção de extrato solubilizado de resíduos sólidos. Rio de Janeiro: ABNT; 2004.

24. Maeda S, Silva HDDA, Magalhães WLE. Aplicação de Cinza de Biomassa Florestal para Plantio de Pinus taeda em Latossolo e Cambissolo de Piraí do Sul, PR. Colombo: Embrapa; 2007. p. 1-6.

25. Manskinen K, Pöykiö R, Nurmesniemi H. Extractability of Heavy Metals in Green Liquor Dregs using Artificial Sweat and Gastric Fluids. International Journal of Civil and Environmental Engineering. 2011;3(1):41-44.

26. Buruberri LH, Seabra MP, Labrincha JA. Preparation of clinker from paper pulp industry wastes. Journal of Hazardous Materials. 2015;286:252-260.

27. Castro AL, Liborio JBL, Pandolfelli VC. Reologia de concretos de alto desempenho aplicados na construção civil: revisão. Cerâmica. 2011;57(341):63-75.

28. Castro AL, Pandolfelli VC. Revisão: conceitos de dispersão e empacotamento de partículas para a produção de concretos especiais aplicados na construção civil. Cerâmica. 2009;55(333):18-32.

29. Romano RCO, Seabra MA, John WM, Pileggi RG. Caracterização reológica de suspensões cimentícias mistas com cales ou filitos. Ambiente Construído. 2014;14(1):75-84.

30. Betioli AM, John VM, Gleize FJP, Pileggi RG. Caracterização reológica de pasta cimentícia: associação de técnicas complementares. Ambiente Construído. 2009;9(4):37-48.

31. Girotto LS, Barbosa MP, Maciel GF. Rheological behavior study of plastic shrinkage and cracking of self-compacting concrete mortars. Revista IBRACON de Estruturas e Materiais. 2014;7(1):24-52.

32. Castro AL. Aplicação de conceitos reológicos na tecnologia dos concretos de alto desempenho. [Thesis]. São Carlos: Universidade de São Paulo (USP); 2007.

33. Botella RM. Reología de Suspensiones Cerámicas. Madrid: Consejo Superior de Investigaciones Científicas; 2005.

34. Senff L, Hotza D, Repette WL. Comportamento reológico de pasta de cimento com adição de sílica ativa, nanossílica e dispersante policarxílico. Matéria (Rio de Janeiro). 2010;15(1):12-20.

35. Gonçalves JP, Moura WA, Dal Molin DCC. Avaliação da influência da utilização do resíduo de corte de granito (RCG), como adição, em propriedades mecânicas do concreto. Ambiente Construído. 2002;2(1):53-68. 